\title{
LAND AND NATURAL RESOURCES: CENTRAL ISSUES IN THE PEACE AND DEMOCRATISATION PROCESS IN NEPAL
}

\author{
Keshab Khadka, Ph.D*
}

\begin{abstract}
Land has been the central issue to human society since the dawn of civilization. Primitive society took it as free gift of nature. Land and livelihood has become the intertwined focal issues in the epochal social transformation processes famous in different era of human civilizations which gave birth to the problem of ownership entitlement, the milestone of turning land as source of state power. Actually, review and reappraisal of land relations has remained always a hot issue in all revolutionary changes and Nepal could not be an exception to this trend. Nepal needs, in fact, a package programme of infrastructure facilitations widening rural access along with strengthening farm input hardware such as full season irrigation, all weather transportation network, cheaper electrification, mechanization with technical supports, cooperatives extending in both output increment and marketing promotions for landless and marginal farmers based on participatory approach. The environment friendly management of water and forest resources to boost up bio-diversity based farming technology is urgently feltneed for which they fought lifelong and supported the peoples' movement.
\end{abstract}

Key words: land and natural resources, peace and democratisation process, package programme, Nepal

\section{INTRODUCTION}

Land has been the central issue to human society since the dawn of civilization. Primitive society took it as free gift of nature. It had two connotations: Man has free access to everything available (produced) on land which did not last long due to rapidly increased population and privatized ownership system. Next was the free use of land to secure livelihood which still survives in one or another fashion. Land and livelihood, thus, become the intertwined focal issues in the epochal social transformation processes famous in different era of human civilizations which gave birth to the problem of ownership entitlement, the milestone of turning land as source of state power. Actually, review and reappraisal of land relations has remained always a hot issue in all revolutionary changes human society has witnessed to determine its various uses and the modes of individual rights thereto. Nepal could not be an exception to this trend as such the half a century long democratic struggles put land reform as top agenda for socio-economic transformations prevailing in this country which had remained stale since the dawn of her statehood. The testimonial is well furnished by

\footnotetext{
* Mr. Khadka is Professor; Department of Economics, Patan Multiple Campus, Tribhuvan University
} 
decade long peoples' insurgency which got "great leap forward" especially in rural areas because of "grab the land" move it initiated at its earlier phase. This paper undertakes to analyse the unfinished issue of land and natural resources in this great watershed context of Nepal when a kingdom for last two millennia has transformed very peacefully into the first Republic of twenty first century. A few words on Nepal:

Nepal, a wonderful country of extreme spatial climate variations from tropical to arctic within a span of 200 kilometers, is located along the southern slopes of the Himalayan mountain range rising to 8848 meters down to the lowland of Terai in the south at only 80 meters above sea level lying between China and India. Topographically the country is divided into three bands running the full length from east to west the Mountain, Mid-hills and Terai (southern plains). The Mountain and Mid-Hills together represent $83 \%$ and Tarai represents $17 \%$ of the total area. Due to this spectacular topographic and climatic variation, Nepal is rich in fascinating biological diversity. She occupies only 0.03 percent of the total surface of the earth (MoPE, 2001) and covers 0.1 percent of the world's land area but has high representation of biotic diversity. It claims 9.3 percent of bird, 4.5 percent of mammal, 2 percent of reptiles, 6 percent of butterfly, 1.0 percent of fish and over 2.0 percent of the flowering plant species of the world. The immense bio- climatic diversity in Nepal supports more than 35 forest types (Stainton, 1972). They are home to 5833 species of flowering plants, including about 248 species of endemic plant and 700 species of medicinal plants. Nepal's landmass is also home to 185 species of mammals, 847 species of birds, 645 species of butterflies, 170 species of fish and other animals (MoPE, 2001).

According to the census of 2001 Nepal had a population of 23151423 which is now estimated at 28 million. Women constitute 50.1 percent of the total population. The population growth rate is 2.25 percent per annum and the population density is 160 persons per sq. $\mathrm{km}$. approximately $85 \%$ population live in village and $67 \%$ relying on agriculture for their livelihood with $0.61 \mathrm{ha}$. of average land holding per family in Nepal. Men owned $90 \%$ and women owned $10 \%$ of the private land in Nepal. Women had no access to inheritance property system till recent past.

Importance of Land and Natural Resources: Socio-Economic Perspectives Land and natural resource provide a fair living standard for average people of Nepal. Those who possess land they are fortunate enough and the remaining unfortunate ones have no alternative but recourse back to nearby fallow land or forest or shallow riverbeds and other marshy lands or any other natural lapse for survival. Let us have an overview of land use pattern. It shows that agricultural cultivated land is 3,398,970 ha, uncultivated arable land 986898 ha, forest including shrub 6306460 ha, pasture land 1757345 ha, etc. Round the year irrigation facility is available only in 214460 hectares. Rest of the land depends on rain. There is unequal distribution of cultivated land. Seventy percent farmers have less than one ha plot. Though, agriculture is the main employment (67\%) sector in the country, less than $5 \%$ people occupy most of 
the fertile land in rural areas. The situation is so worse that it could not meet the food requirement of the people engaged in farming, too, due to low productivity. Land distribution of Nepal is given in Table 1

Table 1: Distribution of Total Land Area of Nepal by Physiographic Region ('000 ha)

\begin{tabular}{|l|l|l|l|l|l|l|}
\hline Physiographic Regions & \multicolumn{6}{|l|}{ Development Regions } \\
\hline & Eastern & Central & Western & Mid-Western & Far-Western & Nepal \\
\hline \multirow{2}{*}{ High Himal } & 470.5 & 224.3 & 882.9 & 1502.5 & 269.0 & 3349.2 \\
& $(16.5)$ & $(8.2)$ & $(30.0)$ & $(35.1)$ & $(13.8)$ & $(22.7)$ \\
\hline \multirow{2}{*}{ High Mountain } & 531.1 & 366.9 & 489.8 & 1147.5 & 424.0 & 2959.3 \\
& $(18.6)$ & $(13.4)$ & $(16.7)$ & $(26.8)$ & $(21.8)$ & $(20.1)$ \\
\hline \multirow{2}{*}{ Middle Mountain } & 980.9 & 931.2 & 1011.8 & 803.3 & 716.4 & 4443.6 \\
& $(34.4)$ & $(34.1)$ & $(34.5)$ & $(18.8)$ & $(36.8)$ & $(30.1)$ \\
\hline \multirow{2}{*}{ Siwalik } & 251.2 & 629.6 & 237.2 & 570.2 & 197.5 & 1885.7 \\
& $(8.8)$ & $(23.0)$ & $(8.1)$ & $(13.3)$ & $(10.2)$ & $(12.8)$ \\
\hline \multirow{2}{*}{ Terai } & 620.4 & 582.1 & 313.8 & 256.7 & 337.4 & 2110.4 \\
& $(21.7)$ & $(21.3)$ & $(10.7)$ & $(6.0)$ & $(17.4)$ & $(14.3)$ \\
\hline \multirow{2}{*}{ Total } & 2854.1 & 2734.1 & 2935.5 & 4280.2 & 1944.3 & 14748.2 \\
& $(100.0)$ & $(100.0)$ & $(100.0)$ & $(100.0)$ & $(100.0)$ & $(100.0)$ \\
\hline
\end{tabular}

Note: Figures in parentheses represent percentages. Source: CBS 2005.

Contribution of agriculture sector in GDP is only $32 \%$ (GoN: 2009). Nepal ranks on $137^{\text {th }}$ among 173 countries with gender related index ranking as 119 th of 146 countries (UNDP: 2008),. Per capita income of Nepal is estimated at less than US \$ 390 which is least in comparison to other SAARC countries and 31\% people are considered below the poverty line officially. Life expectancy of men is 63 years and women 56 years. Women and Girl child are the main victims of poverty. Treacherously, unemployment figures below $4 \%$ and $40 \%$ people are underemployed. The literacy rate of Nepal is 58 percent and of female, only 46 percent (NPC: 2009).

Nepalese economy is based on agriculture and ninety percent rural women are involved in this sector. Women complete most of the agricultural activities from field operations to post-harvest uses and preservations. Unfortunately, women do not have decision making role in land property entitlement or farm management or to choose the crop and cropping pattern. Traditionally women play vital role for the selection and preservation of the seed in Nepal. But high breed seeds of the multi national companies have disturbed this traditional female stronghold and rubbed off their respected role well-founded in social system. Due to lack of land use policies, poor infrastructure development, and haphazard-farming system/practice agriculture production is very low. These issues should be addressed seriously. There is no doubt that both political parties and civil societies have raised the land issues with different colours and positions in Nepal, yet it is never addressed properly to solve ages-bound complications. Major land us pattern of Nepal is highlighted in Table 2. 
Table 2: Major Land Uses Pattern of Nepal Area ('000 ha)

\begin{tabular}{|l|l|l|l|l|l|l|l|}
\hline & \multicolumn{9}{|c|}{ Land Uses } \\
\hline Physiographic & \multicolumn{2}{|l|}{ Agriculture } & Grazing & Forest & Others & Total \\
\hline Regions & Cultivated & $\begin{array}{l}\text { Non- } \\
\text { Cultivated* }\end{array}$ & Total & & & \\
\hline High Himal & $\begin{array}{l}8 \\
(0.2)\end{array}$ & $\begin{array}{l}2 \\
(0.06)\end{array}$ & $\begin{array}{l}10 \\
(0.3)\end{array}$ & $\begin{array}{l}884 \\
(26.0)\end{array}$ & $\begin{array}{l}221 \\
(6.6)\end{array}$ & $\begin{array}{l}2234 \\
(67.0)\end{array}$ & 3349 \\
\hline High Mountains & $\begin{array}{l}245 \\
(8.1)\end{array}$ & $\begin{array}{l}147 \\
(5.0)\end{array}$ & $\begin{array}{l}392 \\
(13.2)\end{array}$ & $\begin{array}{l}510 \\
(17.2)\end{array}$ & $\begin{array}{l}1813 \\
(61.2)\end{array}$ & $\begin{array}{l}245 \\
(8.3)\end{array}$ & 2960 \\
\hline Middle Mountains & $\begin{array}{l}1222 \\
(27.5)\end{array}$ & $\begin{array}{l}665 \\
(15.0)\end{array}$ & $\begin{array}{l}1887 \\
(42.5)\end{array}$ & $\begin{array}{l}293 \\
(6.6)\end{array}$ & $\begin{array}{l}2202 \\
(49.6)\end{array}$ & $\begin{array}{l}61 \\
(1.4)\end{array}$ & 4443 \\
\hline Chure Hills & $\begin{array}{l}259 \\
(13.7)\end{array}$ & $\begin{array}{l}314 \\
(16.6)\end{array}$ & $\begin{array}{l}21 \\
(1.1)\end{array}$ & $\begin{array}{l}1477 \\
(78.3)\end{array}$ & $\begin{array}{l}74 \\
(3.9)\end{array}$ & 1886 \\
\hline Tarai & $\begin{array}{l}(234) \\
(58.5)\end{array}$ & $\begin{array}{l}117 \\
(5.5)\end{array}$ & $\begin{array}{l}1351 \\
(64.0)\end{array}$ & $\begin{array}{l}50 \\
(2.4)\end{array}$ & $\begin{array}{l}593 \\
(28.1)\end{array}$ & $\begin{array}{l}116 \\
(5.5)\end{array}$ & 2110 \\
\hline Total & $\begin{array}{l}986 \\
(6.7)\end{array}$ & $\begin{array}{l}3854 \\
(26.8)\end{array}$ & $\begin{array}{l}1758 \\
(11.9)\end{array}$ & $\begin{array}{l}6306 \\
(42.8)\end{array}$ & $\begin{array}{l}2730 \\
(18.5)\end{array}$ & 14748 \\
\hline
\end{tabular}

Note: * These are non-cultivated inclusions within the mapped agricultural land. Figures in parentheses represent percentages. Source: CBS/ GoN 2005.

The victims of hunger and malnutrition are small landholders and land less people, who are mostly concentrated in rural areas. Among them women are mainly affected by malnutrition and anaemia. South Asia with largest share of world population in poverty has the highest proportion of small holders and land less people. In most of the Asian countries and particularly in South Asian countries, more than 50 percent of people have holdings less than one hectare. In Nepal the majority of land holdings record less than 0.2 hectare. Large landholders dominate local power structures and influence government policies and programs at local as well as central level.

Labor force, not absorbed by other sectors, remains in agriculture creating heavy pressure on unevenly distributed and ill managed-mismanaged land resource. Social justice and poverty reduction is possible through proper management of land resources in a developing country like Nepal. In fact, larger the concentration of land in limited hands, greater the neglect of food production and the high ignoring of distribution effects on poor. Intervention in the land ownership and tenure system should change, thus, the situation Nepal, where the inverse relationship between land holding and poverty is dominant. The productive land use system based on long term vision and design is necessary for overall change of rural land based economy. Thus the right based approach on land urges for change in land ownership structure in favour of better livelihood position as well as increased support through easy input availability \& technological assistance as a part of productivity movement in rural land base of the economy. Therefore land is the key factor for societal change in Nepal. Land-based livelihood strategy cannot be replaced without massive transfer of wage 
labor and self-employed labor including unpaid family workers of the farm families. Fast growth of employment in non-agricultural sectors does not show encouraging trend at the extremely difficult present context. So land based strategy is a long way to go ahead. Thus land is to be considered our focal point in the development strategy of Nepal.

\section{CURRENT SCENARIO}

For the past nearly four decades, the agriculture sector of Nepal has been caught in a spiral of slow growth. Yet, little analytical work appears to have been undertaken to ascertain the principal determinants of this phenomenon, and much less on initiating effective remedial measures. All we know in general terms is that this predominant sector of the economy is still overwhelmingly subsistence-oriented, highly diversified at the farm level (an antithesis of specialisation and commercialisation), and grossly ill served with access to modern productive inputs and technology delivery services. Let us see the survey in Table 3.

Table 3: Growth in Real GDP: Nepal (\%)

\begin{tabular}{|l|l|l|r|}
\hline Items & $1974 / 75-1983 / 84$ & $1984 / 85-999 / 2000$ & $2000 / 01-07 / 08$ \\
\hline Total GDP & 2.95 & 4.93 & 3.22 \\
\hline Agricultural GDP & 1.73 & 2.90 & 2.02 \\
\hline Non-agricultural GDP & 5.23 & 6.87 & 4.23 \\
\hline
\end{tabular}

Note: Growth rates are computed fitting OLS log-linear regression lines.

Source of basic data: Economic Survey, various issues, Ministry of Finance, GoN.

This rather insignificant three percent growth in the country's predominant economic sector employing more than 80 percent of the economically active population and contributing around two-fifths to the gross domestic product is quite inadequate to meet the country's growing food demand, and to trigger a process of overall economic transformation. Actually, this trend, when compared to the annual population growth of about 2.5 percent, present a quite disturbing picture.

It is also noteworthy that the proportion of the economically active population depending on agriculture had fallen by about 13 percentage points from 94 percent in 1971 to 81 percent in 1991 and further 15 percentage points to 66 percent in 2004. On the other hand, the share of this sector in the GDP has dropped more sharply, from around 72 percent in 1974/75 to 40 percent in 1997/98 down to 32 percent in 2008 (GoN: 2009). These disproportionate drops in the sector's share in the total employment and income indicate alarming situation within the sector. 


\section{LAND AND LIVELIHOOD}

Land is still the only source of livelihood for absolute majority of people in Nepal, yet it is not the preferred job of people, specially the young generation. Visibly there are two reasons: a) young people are tired of physical labour the traditional pattern of agriculture operates and b) young people are after quick returns, something meaningful income comparable to other occupations which the current state of arts in agriculture fails to procure. Perhaps, there is third one, i.e, c) climate change and an environmental problem has inflicted degradations in agri-production which is beyond the perception of common farmers. There is no wonder that larger portion of peasantry suffering under subsistence farming and poverty trap have been fighting to change these dimensions that directly affect their livelihood. In their quest to translate it quickly into reality, they adopted specified changing cropping pattern suitable to the surrounding and meet their requirements increasing day by day. The first step was turning grain farming into cash crops such as sugar cane, tobacco, tea, cotton, etc. and then to quick crops such as vegetables, more recently, off season greeneries. Most of the families involved in the non-food cash crop production face food deficit problems. Women and children are deprived of quality food and suffered by malnutrition, because they do not have sufficient land to produce vegetables and fruits to fulfil the family needs. In urban areas, big farmers or business companies are capturing most of the agricultural lands for non-agri-purposes. Most of the lands are used for the business purpose called real states wherever road connectivity exists turning fertile grain producing plots into big apartments, shopping malls and tourist resorts. In this cruel process, small and marginal farmers are driven off the land and farming, and often changed into wage labourers involved in the informal jobs and residing somewhere in squatters.

Modernisation in agriculture has another story. Most of the peasants are loosing their seeds due to the use of high breed seeds. For example, high breed corn replaces local corn, the high breed rice varieties, replace local rice varieties and vegetables are replaced by the high breed varieties of vegetables. High breed varieties demand more chemical fertilizers as well as pesticides. Fertility of the land is decreasing due to the over use of chemical fertilizers. Pesticide resistance is also being increased. There is lack of awareness among farmers on the effect of chemical fertilizer and pesticides. The chemical pesticides replace traditional pest control systems. Chemical fertilizers replace the organic manure or compost manure.

Use of chemical pesticides has affected on human health. For example, reproductive systems and nervous systems are affected. Pesticides are easily found in the remote villages too. Women are victims of pesticides misuse. Their cloths are more open and they do not know about the proper use of the pesticides, because most of the rural women are illiterate and have no or low chance to participate in the training activities. 
Agriculture related employment opportunities are decreased and people are migrated to the cities as well as foreign countries for the employment. National industries are being privatized and people are loosing their jobs. WTO membership has increased the risks in the agricultural sector in Nepal. It is difficult to compete with multi national companies, therefore, peasants are raising the issue "WTO out of agricultural sector".

\section{Natural Resource-based Livelihood Pattern}

The other side of this growing grievance refers to unnecessary private vested interest encroachment on natural wealth, such as forest, water, fallow and wet-lands, high neppe valleys and meadows in the name of development. Traditionally, Nepal has been enjoying a socio-economic life pattern based on community resource use for common benefit in harmony with nature. Thus there are high hills and mountain tops as abode of God, lakes, ponds and wet-lands as holy shrines and rivers as perennial mothers and plateaus and pastures as Devine stage. People respect them and their tradition prescribes that in preserving these resources their prosperity is best served ad infenitum. For this purpose every community has its own indigenous Guthi (Trust) system that looks after the immediate resource pool and its sustainable use defined in very many facets of colourful cultural manifestations and livelihood patterns.

Till the hour, absolute majority of people get their livelihood in harmony with natural resources available in surroundings. The farmers' household set includes land, water and wet-land, forest and fallow land as it counts not only on productivity of farm-land but also the open space for draft animals and the fodder and/or grazing they need to support the system. In a rural settlement like that of Nepal, it means community management of natural resources in different formats conserving even clay and soils, riverbeds and creeks, lakes and swampy spaces, meadows and shrubs without which their life becomes miserable. Their primary concern always focusing on trailing the over-flooding banks and arresting massive land slides so that whatever they have inherited from fore fathers, they can pass to posterity least disturbed. Obviously, this is what the essence and norm of sustainability and this is what the farmers in Nepal simply doing, the generations together in the pious process of nurturing the nature and natural resources to avail the sons of soil a healthy life and secure livelihood. This is reflected in terraced superfine slopes of steep hills full of juvenile rice fields or the long lingering spreads to wide horizon of Terai plains. Unfortunately, this eco-friendly tradition of a cultured livelihood pattern is never recognised in Nepalese politicoadministrative mechanism. Besides, there is gross misunderstanding of agriculture in peoples' perspectives and state's policy response.

People take agriculture as life pattern, a means of subsistence and a most reliable way of life. Because of topographic diversity and equally varied climatic zones coupled with ethno-socio-economic conditionalities, it has different connotations in different ecological belts. 
The high mountains and the Himalayas harbours pastureland-based agri-pattern which permits smaller space for grain farming and highland crops (potatoes, ruby crops etc) occupying larger space. Yet the most important agri-business here is animal rearing - yak to sheep flocks. The colder saddles provide immense potentiality for herbal crops. Trance humans economy dominates the overall livelihood pattern. The peaceful solitude as base for blissful meditation for monks and hermits!

The middle mountains and hills also include deep river valleys, sloppy terraces, dales and gullies rather warm and humid. Actually, these river valleys were the cradle of Nepalese civilizations for millennia thereby identifying and developing new edible crops and domesticating the animals with rich variety of creative cultured life patterns. A single hill expanse boasts all the terrestrial ecological mosaic hosting wide variety of cereals, vegetables, fruits and animals known to humans at different layers of man-made terraces in conformity with natural elevation from hot-wet tropical to cold temperate. No wonder, many of hard labour agricultural activities are turned into merry making traditional festivities in course of history. However, the mutually secluded settlements growing with unique values and norms most suited to the surroundings now ushered into different ethnic groups.

The most prized land of Tarai, the granary of Nepal, is a fraction of great Gangetic plain. The hot-wet summer shower tropics furnish every possibility for grain farming round the year. Peoples' life is at ease and the modern facilities abound across the region. However, till recent past the region was forbidden land due to malaria and other tropical disease, thus an undisturbed broad leaf evergreen forest with rich variety of fauna and flora spread all dotted by indigenous peoples' small clusters for centuries. The last century, specially the latter half, was a great water-shade for this region as the habitation so fast filled it after malaria control that virtually has now turned into most densely populated area with rapid deforestation. Obviously, migrants dominate the domicile loci, both internally (from hills) and externally (from bordering Indian states of Bihar, UP, etc). The chequered relationship resulting in such situation has produced different socio-economic dimensions easy to politicise and manipulate changing livelihood pattern to serve vested group interests. This is how the situation is worsening in Terai at the cost of common peoples' great loss - property, life and peaceful means of livelihood.

Thus the distinct ecological belts with different historical settings and characteristically varied ways of using natural resources for culturally befitting livelihood systems need differential policy responses which never finds ventilated in the body politics of the land. There is no wonder that land reform, though every political party emphasises with top priority, enjoys no uniform support across the land due to these spatial differences. The administrative machinery is in utter dismay as top brass imposes simplistic mono-styled policies leaving wide the discretion to downward hierarchy. Therefore, a change in policy dimension is what desired most in addressing the livelihood patterns in the changed context of natural resource management. 


\section{Land Resource and Conflict: The Politics of Insurgents}

Land management is a central issue of political economy of Nepal which refers to both land tenure and land administration including good governance. After the unification of present Nepal, the rulers prevailed their authority over all lands under the theory that state owns territory absolutely. The mid $18^{\text {th }}$ century conflict in Majh-Kirant, the eastern high mountains and hills, was purely the state intervention in traditional community ownership of ethnic Rai people called Kipat. Similar was the case with then western mountain and hill principalities called Baise and Choubise rajas (22 and 24 hill serfdoms). However, Govt. could control it and state's high hand established firmly (Nepal: 1992). The new order begot a new situation in which the ruling family of Ranas and their lackeys along with war lords of unification bout and high officials amassed large chunk of lands as Birta. Besides, there were cadastral surveys often and better land in Terai awarded to kith and kin of ruling family. So a new kind of feudal land lordship came into existence. The democratic movement of late 1940s was directed against the feudal agrarian structure under the banner slogan "Down with Ranarchy". Much change was expected after the victory of democratic forces in 1951.

But the situation so prevailed till date that nothing substantial was get-done since 1951 Revolution echoing people right over livelihood sources specially land. It's not that nothing was done; actually, there were dozens of attempts, such as, Formation of the Land Reform Commission in 1953; Promulgation of the thirteen-point programme in 1956; Preparation of Land and Cultivators' Records Act 1954; Lands Act 1955; Abolition of Birta Land Act 1957; and Agriculture (New Provisions) Act 1960. But not effective any one as they were all partial and patch work, so only conflict-exacerbating. The most effective of them was the Land Reform Act, 1964. Actually, it was enacted by then king Mahendra to gain ground for his so called Panchayat system upholding despotic monarchy which he inducted after the brutal coup against popularly elected government in the body politic at that time. Yet it was seen by many Madhesis and Tharus as an assault on their livelihood, as migrants were gifted the land by the state. Currently, Terai based sectarians highly politicize it as a great favour of state to hill (Pahadia) migrants.

However, it abolished many forms of land tenures such as, raikar, birta, guthi and kipat etc. and Nepal entered into modem era in ownership relations. The objectives of this reform measure were to secure the right of land holders and tillers so that land productivity could be enhanced. Therefore, it fixed the ceiling of land holdings, protected tenancy rights, fixed rents to the landowner at $50 \%$ of the principal crops, and introduced other measures such as 'compulsory savings schemes' to generate capital for investment in the rural areas. A primary objective was to redistribute land to the landless and small holders. But the land reform was administered ineffectively such that big landholders had enough time to transfer holdings to their kith and kin. Government could acquire only 31,848 hectares out of the total 1.66 million hectares of agricultural land (less than $2 \%$ ) and distributed only 29,123 ha of land (1.5\% of the 
total agriculture land) among the landless. From the perspective of land redistribution and peasants' right, the reform was a total failure. All political parties are aware of this fact and they raise the issue more often.

After Restoration of democracy in1990 again the land issue got fanfare. In 1995, CPN UML led the minority govt. and commissioned Badal Committee to delve into the matter. It produced a fine report with compromised solutions. It aimed at restructuring of agriculture sector and stressed on agrarian reform. But it was never put into practice though his party and he himself was often in Government. However, in 1998, the Act was amended such that land could be registered under the ownership of only a single owner. There had been another amendment in the Land Act 2002 revising the maximum ceiling on landholdings with the objective of redistributing land to the landless/small holders and taking care of other problems like absentee landlords. Land holding ceiling as per the amendment of Nepal is reflected in Table 5.

Table 5: Amended Land Holding Ceiling, Nepal

\begin{tabular}{|l|l|}
\hline Category & Amended ceiling \\
\hline 1. Total Terai Including inner Terai & 10 Bigha \\
\hline 2. Kathmandu Valley & 25 Ropani \\
\hline 3. The remaining hills except Kathmandu Valley & 70 Ropani \\
\hline Ceiling for homestead & \\
\hline 1. Total Terai Including inner Terai & 1 Bigha \\
\hline 2. Kathmandu Valley & 5 Ropani \\
\hline 3. The remaining hills except Kathmandu Valley & 5 Ropani \\
\hline
\end{tabular}

The stalemate land issue holds so much importance that then Deuba govt. (Nepali Congress favouring status quo) came up with fresh program as late as 2003 to weaken Maoist stand on land redistribution. But Maoist had long back overtaken this issue and capitalized it in their favour.

The fact relates with land ownership system and use pattern in Nepal. A citizen can hold entitlement right overland anywhere within the country which allows people to keep land as private property. Though there exists legal binding of confirming to ceiling which is obscure, practically it can be waved easily by simply committing not authenticating. It allows large estates to inherit and keep under ones entitlement for generations. Often such owners do not know their lands which are tilled and cultivated by others as source of livelihood. The core contradiction is that those who own the land are not the actual users and those who use (till and cultivate) the land are not the owners. A survey study conducted by ANPFa in 2003 revealed that peasants without entitlement rights hold $71 \%$ of cultivated land in that year's crop cycle. Thus, the issue is linked not only to a dip in farm productivity and the agrarian crisis, but 
also with social justice, peace and livelihoods. The recognition that land and peace are inter-related is most acutely felt here in the western Tarai. It was the oldest of peasant's struggle area where right to land movement caught national attention long back in 1954. This is where an exploitative absentee landlord system and landlessness exists high. Maoist ignited land-grab movement here in their earlier stage and gained popularity. Actually, the landless peasants, who were kept as bonded labour by absentee landlord themselves, were mobilized to capture the land they were assigned to work upon, So it was as simple as disobey the landlord and refuse to pay anything to him and claim that the land they were cultivating belongs to themselves without paying anything. The message caught whole village and area in Prairie fire as there was no one to resist at that time because the absentee landlord had no strength to go back to village and claim the land. Instead, the landlords sought political patronage of then ruling party, Nepali Congress which was almost confined in headquarters. It helped the Maoist insurgents to consolidate their influence in rural interiors as the peasants had to support them and in exchange they get the land free of cost and obviously, success converged at no time. It was also extended to indigenous peoples' common property pool which turned to claim even state status under federal structure. This helped Maoist to muster popular support at no time and turn into a large party. But the tragedy is that what Maoist did during the insurgency has not yet been legalised. There are often the events of forcefully occupying of fertile land and even the harvest by Maoist supporters (?) reported in the papers even when the Maoist Suprimo was Prime Minister of the country.

\section{Land Reform: Priority Agenda of New Republic}

Do we need land reform? The consensus across the board is yes. But what kind of land reform! Now the table bleaks at ceiling and ownership transfer. Given inequitable land distribution, does the answer lie in reducing the ceiling further to extract land from those who have it and redistribute it? But after fragmentation within families and across generations, most farmers in the Tarai have less than 10 bighas. Half a ropani of land in Kathmandu is more valuable than 15-20 bighas in most districts. It is the hot socio-economic agenda, a complex policy challenge, affecting majority of country's population, and antagonistic classes pitted against each other. If there has to be valuation and ceiling, farmers say, it should be on property and not just land.

The ceiling level is most debated. The UML's Badal commission recommended a ceiling of 4.5 bighas and other policy measures, but was never implemented. Deuba's attempt in 2003 to fix the ceiling at 10 bighas was a step forward, but did not translate into support for the poor landless. It also ignored the cardinal principle that land reform and agrarian reform must go together.

The role of civil society is also very dubious in such critical issue. Apart from occasional civil society seminars and sporadic piece meal policy responses, the land question isn't 
on their urgent socio-economic agenda. Few of them advocate land to the tillers but giving small plots away may only lead to a further dip in production as it will not be profitable for marginal farmers to invest in modern agriculture. Even those with five bighas of land just manage modern living standards, so how will a family with half a bigha of land manage? Will he just end up selling it and becoming landless again? The major question is evolving an agrarian economy which is both profitable and socially justifiable.

This all should not be a sophisticated rationalisation that nothing can be done for the landless. It is important to target the few remaining big jamindars including just ousted royalty who have accrued the landed property illegally over the years. It is also possible to use scattered public land, riverside fallow lands and others called 'elani jagga',(public land left uncared) and take property of the guthis( trusts) which are monopolised by a few people and make use for landless people to start up a modern cooperative farming on high profit. But mere distribution of land to selected landless poor seldom helps change their lives. The core issue calls forth an agrarian revival: irrigation, bio-diversity-based ecological farming, moderate use of subsidised fertilisers, if need be, crop diversification, technical know-how, availability of quality seeds, better market management, cold stores and transportation network, etc.

Will it be addressing the multifarious land issues in modernizing agriculture? If the migration is any indicator, people want to escape from the land for better options. Policy failure to address the poor, who are least equipped for the modern economy, may result in newly legalized farmers pushed out of agriculture while others who are professionally skilled continue to profit from land at their cost. Instead of unnecessarily attracting people in agriculture, it's already late to start exploring nonfarm economy options for employment generation. So land reform cannot just be about rash redistribution of patches of land, as some astute politicians look it up. It has to be in a package deal which addresses all of those relevant lacunas which previous land reforms left untouched. So the need is to prepare a white paper on previous landreform attempts, and conducts a nation-wide survey to come up with baseline data on land ownership, land use pattern and productivity. Balancing individual rights with social justice, and evolving a land and agrarian policy to make best use of biodiversity enriched land resources in favour of small and marginal farmers, landless peasants, women and dalits must be the guiding principles.

\section{KEY ISSUES: HIGH CONCERN OF MOVEMENTS}

\section{Exclusion and Discrimination}

Exclusion and discrimination are some of the major constraints in achieving equitable land titles. Though women and indigenous communities are cultivators to ensure household and national food security and protect and promote biodiversity and environment, their contributions are rarely recognized in policy and practices. The 
lands titles are blatantly denied just on the basis of class caste and gender. They have been working as Kamaiya (now abolished in 2003) Haliya and/or in balighare( annually paid in kind) and mostly paid on kinds such as fixed amount of grain on certain period of the year but denied of their claim over the land despite their generation-to-generation tilling services. Similarly, large masses of indigenous and Terai communities are denied of land rights due to lack of their citizenship. This has been further complicated because of lack of their representation in decision-making political level. More than two-third (67\%) of Dalits have no land ownership entitlement.

Another denied category is women, whose rights are denied due to the categorization of girls as "passer by" and women as "passer in" in the family. So there is no proper mechanism to address their concerns either in their parental or marital home place. Consequently, they are excluded from various benefits associated with land titles. The land titles do not only secure the permanent form of their settlement, it also equally raise the level of confidence to those communities to improve their bargaining capacity and subsequently able to challenge other forms of oppression within households and the society. This highlights the importance of land titles not only for economic improvement but also for improving their relative position within and outside household. Only 10\% women have land entitlements and the real ownership of landed property is still less as more than $80 \%$ of land entitlement of such women concentrates in urban areas for homesteads for legal reasons.

\section{Diseconomy of Land Holding Size}

Disintegration and fragmentation of holding is one of the major systemic problem that rural livelihood faces when population is raising fast and smaller farmers having larger family size. It's a matter of pity that the entitlement right over ancestral property is so well grounded in traditions that reversal of which is simply unthinkable. Table 6 shows the national scenario of population density in Nepal.

Table 6: Population Density (persons per sq. km) in Ecological Zones, Nepal, 1971-2001

\begin{tabular}{|l|c|c|c|c|c|c|}
\hline \multirow{2}{*}{ Year } & \multicolumn{3}{|}{ Density in total Land Area } & \multicolumn{3}{c|}{ Density in cultivated land area } \\
\cline { 2 - 7 } & Mountains & Hills & Terai & Mountains & Hills & Terai \\
\hline 1971 & 22 & 99 & 128 & 700 & 690 & 330 \\
\hline 1981 & 25 & 117 & 193 & 800 & 820 & 500 \\
\hline 1991 & 28 & 137 & 253 & 880 & 960 & 660 \\
\hline 2001 & 79 & 102 & 125 & 490 & 640 & 780 \\
\hline
\end{tabular}

Sources: CBS 1987: 15; CBS 1995: 135 CBS 2004

The high man-land ratio has forced growing population to move into inferior land resulting in land degradation and fragmentation 
Land degradation: Land degradation is due to (a) natural (bio geophysical) causes, (b) human causes, or (c) a combination of both. Owing to the complex features of the mountain terrain, the nature of land degradation varies greatly in Nepal. Landslides are the most important factor in land degradation in Nepal. Landslides occur almost every year, particularly in the sloping areas of high mountains and low hills during the monsoon season. The consequences of landslides include topsoil erosion; damaged and destroyed roads, trails, and bridges; loss of land, lives, and property; and siltation in low-lying areas resulting in unproductive land (Figure 3.1). About 1.8 million ha $(13 \%)$ of the land in the Mountains is estimated to be severely degraded by landslides (CBS 1998).

Fragmentation of holding: Fragmentation and parcelling into smaller pieces has been the rising trend as the land prices are in spiral coupled with homestead craze in urban and sub-urban areas. It has negative effect in cereal production as it occupies $85 \%$ of agri-outputs. The per capita food production of $376 \mathrm{~kg}$ in 1975 has come down to 277 $\mathrm{kg}$ in 1995 and further to $230 \mathrm{~kg}$ in 2005

Defective land ownership and inheritance pattern has resulted in unnecessary fragmentation of holding. It's especially problematic with small and marginal farmers as the small size of their possessions are further divided among heirs turning them into landlessness at no time. The common law practice is that every child has right to paternal property, a social necessity overtime to facilitate means of livelihood for each. The negative effects on farm labour and productivity is so much that often it leads to working poor and perpetuation of poverty. The overall picture is presented in Table 7.

Table 7: Average parcel of land/ household/ hectare

\begin{tabular}{|l|l|l|l|}
\hline Regions & No. of HHs/parcel & No. of parcel/ha & Av. Area/parcel: ha \\
\hline High Mountains & 4.6 & 6.8 & 0.15 \\
\hline Mid hills & 3.9 & 5.1 & 0.20 \\
\hline Terai plains & 3.9 & 3.1 & 0.32 \\
\hline Nepal & 4.0 & 4.2 & 0.24 \\
\hline
\end{tabular}

Source: $C B S /$ GoN 2005

\section{Climate Change and Reduced Production}

Climate change has an important impact on Nepalese agriculture as the landscape, elevation and ecological variation includes difference (ICIMOD/ UNEP, 2007). Besides, more than $80 \%$ of precipitation occurs in the monsoon during June to September. Increase in temperature and vents of erratic rainfall directly affect the agriculture and food supply through their effects on crops. Agriculture is sensitive to short-term changes in weather that affect the production of crops. Insufficient rain and increasing temperature cause drought, whereas intense rain in short period reduces 
ground water recharge by accelerating runoff water volume causing floods. Both the situations induce negative effects in the agriculture. The climate change also causes disruption in normal weather pattern changing intensity and duration of monsoon.

The US Country Study of Nepal (USCSP, 2008) used records from 22 stations during the 1979-2008 period. The temperature differences are most pronounced during the dry winter season, and least during the time of the monsoon. There is also significantly greater warming at higher elevations in the northern part of the country than at lower elevations in the south. The results for temperature changes with a doubling of $\mathrm{Co} 2$ are summarized in Table 8.

Table 8: Temperature Variation

\begin{tabular}{|l|l|l|l|l|l|l|l|l|l|l|l|l|}
\hline Category & Jan & Feb & Mar & Apr & May & Jun & Jul & Aug & Sep & Oct & Nov & Dec \\
\hline Observed & 11.9 & 13.7 & 18.0 & 22.0 & 23.8 & 25.0 & 24.6 & 24.7 & 23.5 & 20.9 & 16.9 & 13.2 \\
\hline Projected & 15.8 & 17.3 & 20.9 & 25.1 & 26.9 & 28.6 & 26.2 & 26.4 & 26.6 & 24.6 & 20.3 & 15.8 \\
\hline $\begin{array}{l}\text { Percent } \\
\text { Change }\end{array}$ & 32.4 & 25.9 & 16.1 & 13.9 & 12.8 & 14.2 & 6.3 & 6.9 & 13.0 & 17.7 & 20.1 & 19.3 \\
\hline
\end{tabular}

Source: USCSP, 2008

The data given in Table 8 show that there is reasonably high confidence that the warming trend already observed in recent decades will continue through the 21 century. As 80 percent of the Nepalese population depends on agriculture for a livelihood and follow traditional cultivation practices, relying on rainwater and the seasons, any changes in climatic conditions affecting rainfall patterns will have an adverse impact on the livelihoods of most of the Nepalese people.

Nepal's agriculture will face many challenges over the coming decades as the soils are degrading and water resource constraints. These conditions may be worsened by climate change. Warming by more than $2.5^{\mathrm{C}}$ may not only cause most of the irrigated terraces turned into rain-fed land but also snow-line shift in the Himalayas causing drastic change in hydrology and, thus, decreasing production significantly. Decline in food production would lead to more malnutrition and huge consequences particularly for children and women.

\section{Landlessness, Farm Labour and Squatter Dwellers}

Integrated Development Systems (IDS) has carried out a study entitled "Rural Landlessness in Nepal which is based on secondary sources of date. The study notes that despite the reform measures performed so far in the country the distribution of landholding is still much skewed in Nepal and the situation has not been changed much for the last 20 years. The study has listed number of causes of rural landlessness; they are demographic pressure, historically defective land tenure system, and 
ineffectiveness of land reform of 1964, heavy reliance of small farmers on private moneylenders in absence of institutional sources of credit, underdevelopment of non farm sectors and migration of seasonal laborers from India due to the open boarder with it.

A CIRDAP study has stated that the extent of landlessness in Nepal, considering both the landless and near landless, is quite high. The study reports that the majority of the farms households in the rural areas consist of marginal and small farmers. The small size of landholding, as the study argues, is largely responsible of rate poverty of the rural masses as the produce from land is insufficient to meet their basic needs. Moreover, according to the study, the widespread prevalence of the tenancy system deprives farmers of the opportunity to benefit from the new technology of production using modern inputs such as improve seeds, chemical fertilizers and pesticides.

The study, regarding the cases of landlessness and rural poverty in Nepal, argues that historically defective land tenure system, unbalances economic development and poor resource endowment of landless households could be identified as the principal causes of landlessness and rural poverty in Nepal. Moreover, the study points out that the migration landlessness and rural poverty in Nepal. Moreover, the study points out that the migration of people from the hills to the Terai in search of arable land has further aggravated the problem. The study has suggested some policies to solve the problem of growing landlessness in Nepal, as the study writes:

The problem of rural landlessness should be solved within the broad framework of agrarian reform. Planned resettlement, based on non farm activities, should be emphasized as an alternative to a land based resettlement program. Increasing employment opportunities for the landless could be achieved through the adoption of new production technologies. The rural works programs should aim at providing employment during the slack agricultural season.

\section{Bonded Labour (Kamaiya, Haliya, etc)}

Though Nepal is declared young Republic of $21^{\text {st }}$ century, feudalistic pattern still reins the country rampant specially, in rural livelihood system that involves land and other natural resources. The irony with landless rural poor is not only the resource denial but also the large family size which compels them to work for landlords to feed the growing mouths. Besides, the lack of alternative means of livelihood in rural setting and the large chunk of landed property captured by land-owner in course of long historical accidents furnishes an undesired environment for submission of juvenile youth cohort to heinous bonded labour in different forms, such as, kamaiya (who takes the land in rent and does household work for landlord), Haliya (farm labour often residing in landlords' home in annual contract basis) gothke (one who looks after goat and sheep flocks) shyangtan (animal porter and yak herd watchman in high hills) etc. 
Actually, abolition of bonded labour is a long cry upheld by democratic movements and peoples' demonstrations. As a result, kamaiya was abolished in 2004, but they are simply displaced from landlords' responsibilities without any provision of alternative means of livelihood which has made a mockery of liberated kamaiya in contemporary social movements. The issue concerns not only the land reform empowering land tillers but also the agrarian reforms that revolutionises the all sets of rural livelihood systems.

\section{GENDER ISSUE}

Better achievement of social well-being is possible in the full participation and partnership of both women and men. The decision making in Nepal is primarily dominated by men, though women spent most of their time related to family wellbeing.

Long back a study showed that the time spend by women in field work, animal husbandry, food processing and fuelwood, fodder and water collection is nearly double that of men- 4.9 compared to 2.6 hours per day. When income earning activities and domestic work are added, the average workday for women is 10.8 hours and for men 7.5 hours. Much of women's daily activity centres on the basic resources - wood, water, land, fodder, crops and livestock, the production of food, shelter, energy and clothing and, ultimately, the concern for human health and family well-being (IUCN, 1988).

Similarly, some locally formulated forest user-groups in rural Nepali communities where female members are also involved have already proven that local community groups are more effective at enforcing common agreements and cooperative actions when the local distribution of forest products is more equal and the benefits are shared more equally. This then provides a local case of how efficiency and equality go together. Better sharing provides an incentive for better coordination in managing local public goods, which increases productivity for everyone (World Bank 1997). A recent survey research witness that women position in land management, product marketing and ownership transfer is weak and insignificant (ANPFA/ SAAPE: 2009)

\section{Urban and Sub-urban Land and Settlement (Real Estate Business)}

Another significant problem arising very fast in Nepalese land and natural resource management is rapid and erratic urbanisation. In the absence of settlement mapping plan, mushroom growth of urban concentrations overnight at fertile plains has been recent phenomena. It has significantly increased the non-farm use of fertile land very objectionably. Besides, land pooling and real estate business has flourished in sub-urban areas and the prices of land sky-rocketing. The first victims of this land business are small and marginal farmers turning them into landless farm workers. The objectionable factor is that it transfers precious land to non-farm plots, i e, from 
food producing livelihood source to profit mongering plotting business. Actually, this is how the land grabbing proceeds on and this has been a very flourishing business recently, especially after the peace-process began. Since there is comparatively peaceful environment people have a craze moving towards town and cities now, if possible, to capital city of Kathmandu, if not, to nearby townships, largely facilitated by remittance. The government lacks concrete policy in this regard which is unscrupulously exploited to cook such very unwanted recipe inviting socio-economic contention in near future. Social movements are taking it very seriously and developing definite position that non-farm land accumulation in any form is totally unacceptable and objectionable outright.

Land Issue in Conflict Transition Land has been the most contentious factor in these days of rather uneasy peace process. As said earlier the insurgent Maoists are committed to have a confiscatory land reform programme which favours their followers who are occupying lands in rural areas since those days of armed struggle. The main argument behind this reasoning may be socio- economic justice by doing away with feudalistic land relations. But the real motive lies on strong vote bank creation for Maoist as they are now to fight elections competing with other political parties. Actually this was one of their main slogans in the last election of Constituent Assembly in which they turned out as largest party. As soon as, $\mathrm{Mr}$ Prachanda, Maoist suprimo, formed his government under his Premiership, he constituted land reform commission with strong mandate. But the commission could not progress ahead as expected because the situation was not that simple. The coalition partners were not convinced of the Maoist actions and very suspicious, too, specially Nepali Congress (NC). Because most of the land Maoist fielders are holding till now belongs to Congress stalwarts, NC vehemently opposed such schemes, so stalemate. The other political forces are in favour of moderate land reform that pays at least reasonable compensation to the land which is above agreed upon ceiling. The present context is so volatile on this issue that CPN (UML) proposes, realising its significance, a comprehensive agrarian reform for total transformation of Nepalese society. Present govt. has constituted new Land Reform Commission to look into the matter rather deeply to reach to an acceptable consensus.

An opinionaire, in this regard, was surveyed among the major political parties which witnessed parallel gap in their respective positions. All agreed on land reform in principle but not the Terai based major ones, such as, Madheshi Janadhikar Forum, Terai Madheshi Loktantric Party, Sadhbhavana Party, having strong say over game of government formation at this hung parliamentary critical period. They took common position that land reform is not their issue but a deliberately construed plot pahadia ruling clique to create confusion in body politic of Terai.

Regarding the issues of slum dwellers and women's land right they are some what sentimental rather than rational. They pretend to be most forward on these issues 
but practically very weak in stand per se. actually, most of the party stalwarts showed their ignorance regarding climate change and its repercussions. Similarly, they had no concrete programme to address fragmentation and the diseconomy of holding size except rudimentary sceptics on cooperatives. On the whole, they present hear-say matters rather than their own analysis based on the real deeds. Such leadership without clear vision endangers any good plan to operate and most often ineffective in delivery. This is the stark reality of post republican small years of Nepal when procrastination pronounces instead of achievements.

THE WAY AHEAD The main thrust of social movements regarding land and natural resources management in the changed context of JANA-ANDOLAN (Peoples' Movement) II is to redress justifiably the grievances as the felt-need of the users of these resources. It naturally places peasants at the center as they derive livelihood for generations nurturing these precious natural wealth but denied of their legitimate rights over them. Actually, the peasants, in course of decade long struggle, have analyzed the specific feature of the country and its agricultural sector, which is developing towards the industrialization and professionalization and specialization. They mean working with efficiency and bring forth the new concept of environment and sustainable agricultural development on peoples' right based frame to improve the rural lot. They are looking into the process and prospects of agro-industrialization and envision it into the national aggregative whole. They would not only reveal their efficiency in playing contributive role and leadership in the overall development process by uplifting agriculture as leading sector but also help to brace up the new challenges arising in the agriculture reforms thereof over time.

At this juncture, one can safely conclude that there is no alternative to comprehensive agrarian reform program in favour of small and marginal farmers along with widening access to land and productive resources for landless peasants. As per the absolute majority of responding peasants strongly demanded such program must begin with progressive landownership management, abolition of absentee land lordship, implementation of land use policy and mapping, etc with clear vision of social transformation process.

Nepal needs, in fact, a package programme of infrastructure facilitations widening rural access along with strengthening farm input hardware such as full season irrigation, all weather transportation network, cheaper electrification, mechanization with technical supports, co-operatives extending in both output increment and marketing promotions for landless and marginal farmers based on participatory approach. The environment friendly management of water and forest resources to boost up bio-diversity based farming technology is urgently felt-need for which they fought lifelong and supported the peoples' movement. 
The main contention lies in institutional ownership reforms for modern management of land and other natural resources for which civil society is struggling so hard for so long. The great confusion lies in ownership pattern: land as private property negotiable in any form for private purpose or a source of livelihood of people. If it is the second option this Republic decides to proceed, it visualizes a system change which needs land use mapping. The new arrangement runs state as owner of land property which can be delegated to community. It reframes a system of community ownership under statutory provisions and citizens as lease holders renewable for generations but not an individual salable commodity as it prevails now. The danger of strong hand of corrupt state practices at the cost of common people rules out in this arrangement. Community ownership addresses most of problems faced currently due to individual ownership which constantly throws away a section of people always landless.

Actually, there may be a long list of 'dos' and 'undoes' but the social movements are well aware that without hot persuasion and mounting pressure upon the ruling clique, no program will come off that much easily in favour of common people. The hard lesson they learned is that, to assert their rights, strong movements are the golden path they have devised till now. They believe only on their own concerted efforts and broader unity among fraternal communities en masse.

\section{Bibliographies}

Action Aid, Pakistan (2001). Corporate Farming Ordinance (compiled version: English)

B. K,Manbahadur (2007). Social Dimensions of Dalits (in Nepali), Jana Utthan Pratisthan, Anamnagar, Kathmandu

Behera, N. Chadha (2006). Women and Migration in Asia: Gender, Conflict and Migration, Vol. 3 (New Delhi: Sage Publications).

Byrne, B. (1996). Gender, Conflict and Development, Vol I: Overview, BRIDGE Report 34, Brighton (BRIDGE/Institute of Development Studies, University of Sussex: UK) www. ids.ac.uk/bridge/ (Accessed on 11 December 2005).

Caritas Nepal (2005). Caravan of IDPs (Kathmandu: Caritas Nepal).

Castles, Stephen (2006). Forced Migration and Social Transformation, Paper Presented at Summer School in Forced Migration, 3-21 July 2006, Refugee Studies Centre, Oxford University, Oxford.

Central Bureau of Statistics (2003). Population Monograph of Nepal (Kathmandu: CBS), Vol. II.

Chapagain, D. P. (2001). Land Agriculture, IUCN, Kathmandu, Nepal

Department of Labour and Employment Promotion (DoL) (2005). Datasheet of Foreign Labour Migration (Kathmandu: DOLEP). 
Dulal, B.B. (2004). Bhumima Dalitko Swamitwa (Land Ownership of Dalits), Unpublished monograph, Sustainable Livelihoods Forum, Kathmandu

Ghale, Yamuna (2005). Land in the Realm of Exclusion and Globalization, a paper presented at Seminar organized by FIAN, Dhulikhel, Nepal

Gurung (2003). Nepali Nationalism in DV Gurung (ed), Nepal Tomorrow: Voices \& Visions (Kathmandu: Kosheli Prakashan), pp 1-13.

Gurung, Ganesh and Pathak, Pratap K. (2007). Towards a National Safe Migration Policy for Nepal, Paper Presented.

Gurung, H. (2006). Human Development, From Exclusion to Inclusion: Socio-Political Agenda for Nepal (Kathmandu: Social Inclusion Research Fund (SIRF), pp 1-13.

Gurung, H. (2006). State Ideology of Class, From Exclusion to Inclusion: Socio-Political Agenda for Nepal (Kathmandu: Social Inclusion Research Fund (SIRF), pp 11-14.

International Displacement Monitoring Centre (IDMC), (2007). Handbook on Housing and Property Restitution for Refugees and Displaced Persons Norwegian Refugee Council (NRC): Norway.

KC, Bal K. (2008). International Migration in Nepal, Asian and Pacific Migration Journal, Vol. 17, Nos. 3-4, 2008, pp. 287-309.

Khadka, Keshab (2008). Food Sovereignty: Alternative Model of Development, Jan Utthan Pratisthan, Kathmandu, Nepal

Khadka, Keshab; Dahal, Madhav, and Samudra K. C. (2009). South Asia Free Trade Agreement and its impact in Agricultural Sector of SAARC Countries, ANPFa and SAAPE, Kathmandu, Nepal

Khadka, Keshab; Banskota,B; Kadariya, Ishwori P. (2010). Impact of Climate Change on Food Security Under Market Mechanism, ANPFa and SAAPE, Kathmandu, Nepal

Khatiwada, Padma P. (2004). Internally Displaced Persons (IDPs) in Nepal: Problems and Challenges, in Lok Raj Baral et al (eds) Nepali Journal of Contemporary Studies, Vol. V, No. 2 (Kathmandu: Nepal Centre for Contemporary Studies)

Lumsali, Rishi R. (2002). Land Issus in Nepal, paper to be Presented at the Regional Workshop on Land Issues in Asia, Phnom Penh, Cambodia

Musembi, C. N. (2004). Gender, Food and Hunger, Action Aid International

Mainali, A. (2005). Land Reform: Still a distant Dream, Sancharika Samuha, Kathmandu, Nepal

MoAC/UNDP (2004). Disaster Risk Reduction in Food and Agriculture Sector: Implementation Manual (Kathmandu: Ministry of Agriculture and Cooperatives and UNDP)

Ortner, Sherry B. (1995). Resistance and the Problem of Ethnographic Refusal, Comparative Studies in Society and History, Vol. 37, No. 1, pp. 173-93. 
Royal Norwegian Embassy Kathmandu (2008). Report on Koshi Flood, http://www.reliefweb. int/rw/dbc.nsf/doc108?OpenForm\&rc=3\&emid=FL-2008-000104-NPL, Accessed on 15 January 2009.

Sen, Amrayta (1997). Social Exclusion: Concept, Application, and Security, Social Development Papers No. 1 Manila: Asian Development Bank to UNHCR by Country/Territory of Asylum, end-2006, (Tables 1 \&11), www.unhcr.org/statistics/Nepal/Table1,11 (Accessed on 25 October 2007).

UN/OCHA (2008). Mid and Far Western Floods and Landslides OCHA Situation Report No. 5, http//www. un.org, accessed on 26 January 2009.

UNDP (2004). Reducing Disaster Risk: A Challenge for Development. New York: UNDP.

UNHCR (2007). Refugees, Asylum-seekers, Internally Displaced Persons (IDPs), Returnees (refugees and IDPs), Stateless Persons, and Others of Concern

UNFPA (2006). State of World Population 2006: A Passage to Hope Women and International Migration (New York: United Nations Population Fund).

Wily, L. A., Chapagain D. and Sharma, S. (2009). Land Reform in Nepal: Where it is Coming From and Where It is Going? The Findings of a Scoping Study of Land Reform for DFID Nepal.

WB (2010). World Development Report, World Bank, Washington

WB (2008). World Development Report, World Bank, Washington

WB (2005). World Development Report, World Bank, Washington

WB (2003). World Development Report, World Bank, Washington

WB (2000/2001). World Development Report, World Bank, Washington

UNDP (2009). Nepal Human Development Report 2009: State Transformation and Human Development, UNDP Nepal.

UNDP (1997). Nepal Human Development Report 1997, Oxford University Press, New York. 